Article

\title{
Regional Organizations and Responsibility to Protect: Normative Reframing or Normative Change?
}

\author{
Carla Barqueiro *, Kate Seaman and Katherine Teresa Towey \\ School of Public and International Affairs, University of Baltimore, Baltimore, MD 21201, USA; \\ E-Mails: cbarqueiro@ubalt.edu (C.B.), kseaman@ubalt.edu (K.S), katherine.towey@ubalt.edu (K.T.T.) \\ * Corresponding author
}

Submitted: 11 April 2016 | Accepted: 30 June 2016 | Published: 11 August 2016

\begin{abstract}
The adoption of the principle of the Responsibility to Protect (RtoP) by all United Nations General Assembly (UNGA) member states in 2005, and its reaffirmation in dozens of United Nations Security Council (UNSC) resolutions, indicate that there is a growing consensus around the world that egregious human rights violations necessitate a cooperative and decisive international response. But just as the political debates raged surrounding the precise articulation of RtoP between 2001 and 2005, so too goes the contemporary debate surrounding the implementation of RtoP. Regional divergences in RtoP implementation, in particular, have been noted by many scholars, as regional organizations implement those elements of RtoP that best suit their policy goals. This paper will apply recent scholarship on normlifecycles, specifically on "norm localization" to the operationalization of RtoP by regional organizations. We seek to explore regional divergences on RtoP implementation between the European Union (EU), League of Arab States (LAS), and the African Union (AU) on Libya and Syria. From this assessment, three main arguments will be put forward: (1) regional organizations remain politicized, reframing RtoP in divergent ways that dilute the strength of the norm, (2) politicization of the RtoP discourse constrains regional norm localization processes, (3) politicization and reframing of RtoP inhibit regional normative change and limit the potential for timely and decisive responses to protect civilians.
\end{abstract}

\section{Keywords}

African Union; European Union; League of Arab States; norms; regional organizations; Responsibility to Protect

Issue

This article is part of the issue "Supranational Institutions and Governance in an Era of Uncertain Norms", edited by Russell Alan Williams (Memorial University, Canada) and Reeta Tremblay (University of Victoria, Canada).

(C) 2016 by the authors; licensee Cogitatio (Lisbon, Portugal). This article is licensed under a Creative Commons Attribution 4.0 International License (CC BY).

\section{Introduction}

With the adoption of the Responsibility to Protect (RtoP) in the World Summit Outcome Document (WSOD) by the United Nations General Assembly (UNGA) member states in 2005, and its reaffirmation in multiple UN Security Council (UNSC) resolutions since 2006, scholarly and political debates have shifted from a focus on the "what" questions concerning the conceptual parameters of the evolving norm, to the "how?" and "under whose authority?" questions surrounding its implementation. Indeed, it is clear that the
2005 WSOD articulation of RtoP centralized authority for sanctioning collective military intervention exclusively within the UNSC. Given the stalemate of the P-5 member states on Syria following the controversial intervention in Libya by NATO forces in 2011, and even though the connection between these two cases and the action and inaction taken in turn has been much debated (Bellamy, 2014; Morris, 2013), what is clear is the extent to which RtoP has become politicized within the Security Council. This politicization and subsequent inaction has increased pressure on the United Nations (UN) to empower regional organizations to take a 
greater role in implementing RtoP, particularly given the unlikely immediate possibility of UNSC reform.

Regional organizations, however, are not a panacea to the challenges of implementing RtoP. As has been noted by many scholars, regional organizations often face challenges associated with lacking resources and capabilities to ensure enforcement of security mandates, have adopted divergent and inconsistent mandates related to RtoP, and suffer from similar deficiencies associated with multilateral decisionmaking, including consensus-based (frequently lowest common denominator) agreements which overemphasize rhetorical commitments over the practical responses to the protection of civilians (Taft \& Ladnier, 2006). Still, the role of regional organizations, particularly in peacekeeping operations, and directing the conceptualization of the RtoP principle itself, has been argued to convey greater international legitimacy to global initiatives on the protection of civilians from mass atrocities (Bellamy, 2011; Haugevik, 2009).

This paper seeks to explore the role of specific regional organizations, namely the European Union (EU), the League of Arab States (LAS), and the African Union $(A U)$, in responding to mass atrocity crimes in Libya and Syria. These organizations have broad mandates that include, but are not limited to, security, unlike the more restricted security-focused mandate of the North Atlantic Treaty Organization (NATO). As such, their security mandates are more likely to be informed by their other policy areas, including in the area of human rights protection, development, and human security. Specifically, this paper seeks to explore whether regional rhetorical commitment and initiatives on RtoP have strengthened the international community's implementation of RtoP, whereby operationalizing the concept has meaningfully enhanced regional capacity to protect civilians from mass atrocity crimes.

\section{Background on the Responsibility to Protect}

The RtoP doctrine originated out of the recognized need to reconsider the United Nations Charter of 1945 and shift international norms from a focus on the rights of the nation-state to prioritizing the rights of the individual. From this, a nuanced debate began regarding how the international community could shift from "state-based collective security" to "human security", particularly how to align moral authority on issues of interventionism with legal and political legitimacy (Chandler, 2004, p. 60). This debate then spawned discourse on understanding the relationship between intervention and state sovereignty and creating a new norm addressing the parameters for action in the face of mass atrocities, while not diluting the sovereignty of the host state.

Chandler (2004) asserts that the quest for international unity regarding the processes and norms related to humanitarian intervention was championed by UN
Secretary General, Kofi Annan, at the 1999 and 2000 UN General Assemblies. In response to Annan's discussion, Jean Chrétien, then Canadian Prime Minister, called for the establishment of the International Commission on Interventionism and State Sovereignty (ICISS) tasked with developing a comprehensive framework for legitimizing humanitarian intervention (Chandler, 2004). The completion of the project resulted in the first use of the term "responsibility to protect" in a report titled, The Responsibility to Protect, which called for $3 \mathrm{R}$ - the responsibility to prevent, the responsibility to react, and the responsibility to rebuild (Chandler, 2010). Published later in 2005, Annan's report, In Larger Freedom, revised the three pillars of the ICISS report, to include the responsibility of the state to protect its citizens, international assistance to support capacity-building of the state, and timely and decisive response by the international community (Chandler, 2010). A product of the UN World Summit in September 2005, the WSOD included several paragraphs on RtoP in line with the modifications authored by Annan, and all participating UNGA member states adopted them by consensus.

The core tenant of RtoP doctrine is that each participating state bears the responsibility to protect its citizens from mass atrocities, and, in the case that such efforts are inadequate, the greater international community has the responsibility to assist the state with this mandate, and in select cases, intervene as a last resort (United Nations, 2005). As Paris (2014) highlights, the doctrine prioritizes peaceful means of protection, but also permits the use of coercive force by the international community in extreme cases. The variation in potential RtoP cases that could trigger intervention has left it vulnerable to politicization. One main argument regarding the weakness of RtoP, championed by Paris (2014) is the "mixed motives problem." The distinction between altruistic military intervention and war is politically pertinent because the responses will be different for an operation that aims to protect civilians versus an operation that is a "self-interested war" (Bachman, 2015; Paris, 2014, p. 572). However, in practice, military action almost always has a selfinterested component (Evans, 2004). Nonetheless, RtoP still faces structural challenges associated with self-interested rather than humanitarian intentions on the one hand, and the more significant problem of lacking self-interest or political will to protect civilians in countries without geopolitical importance to global powers on the other. Deadlock at the UNSC in key cases, including on Darfur and Syria, has highlighted these challenges, and led to calls for regional organizations to take a greater role on RtoP.

\section{Regional Organizations as Collective Security Actors}

The role of regional organizations within global gov- 
ernance, and specifically in supporting international peace and security, has a long history. The United Nations Charter refers to the role of regional organizations under Chapter VIII in Article 52 stating:

"Nothing in the present Charter precludes the existence of regional arrangements or agencies for dealing with such matters relating to the maintenance of international peace and security as are appropriate for regional action provided that such arrangements or agencies and their activities are consistent with the Purposes and Principles of the United Nations." (United Nations, 1945, art. 52)

The Charter also asserts that "The Security Council shall encourage the development of pacific settlement of local disputes through such regional arrangements or by such regional agencies", while the UNSC can "utilize such regional arrangements or agencies for enforcement action under its authority" (United Nations. 1945, art. 52 \& 53). While the founding members to the UN positioned the UNSC as the ultimate arbiter of international peace and security, they also viewed the role of regional organizations and other inter-governmental bodies as supporting global governance efforts to ensure pacific settlement of disputes and security enforcement measures (Haugevik, 2009; Seaman, 2015). As such, regional organizations were positioned to support global governance decision-making and implementation measures at the highest levels.

With the ongoing contemporary challenges the UNSC has faced in terms of legitimacy in security matters, as well as in garnering political consensus for peace and security enforcement mandates, regional organizations have been increasingly relied upon in peace support operations. We have observed the African Union (AU) operation in Sudan since 2003 (in partnership with the UN); the Economic Community of West African States (ECOWAS) operations in Liberia and in Sierra Leone in 1990s; and the North Atlantic Treaty Organization (NATO) operations in Bosnia and Kosovo in the 1990s, and in Libya in 2011 as examples of this growing regional role in implementing global security mandates. Indeed, as Bures (2006) argues, the 2004 High Level Panel on Threats, Challenges and Change built on the 2000 Brahimi Report on peacekeeping reform, arguing that Chapter VIII arrangements need to be more heavily relied upon to further enhance the UNSC's capacity to prevent and respond to security threats.

Regional organizations have also been elevated as viable security actors that could fill the governance and implementation gaps as they arise. The report of the International Commission on Intervention and State Sovereignty (2001), Responsibility to Protect, in 2001 first outlined the role of regional organizations in providing early warning on emerging human rights crises arguing that "Greater involvement by regional actors with intimate local knowledge is also crucial" since "Regional actors are usually better placed to understand local dynamics" (ICISS, 2001, p. 22). In extreme cases, and as a last resort, the ICISS report also advocated for the evocation of Chapter VIII of the UN Charter, where regional organizations can support the enforcement capacity of the UNSC (ICISS, 2001, pp. 64). Most controversially, the ICISS report argued that if the UNSC could not act in a timely manner to protect civilians from mass atrocities, the UNGA under the "Unifying for Peace" clause, or regional and/or sub-regional organizations, should take up the charge (ICISS, 2001, p. xiii).

Not all regional organizations are alike, however. As Haugevik (2009) has argued, regional organizations differ significantly in terms of the extent to which they possess a formal responsibility to protect civilians, adequate capacities, and sufficient political will to undertake "soft" and/or "hard" RtoP operations. Additionally, regional organizations face some of the same challenges that global organizations do. There can be significant obstacles to gaining strong collective mandates due to consensus-based decision-making, they frequently rely on resources and capacities that are a reflection of a single member state's commitment to regional cooperation, and increasingly they can be co-opted by a strong state member's interests and political posturing. The challenges they face surrounding consensus, capacities, and co-option have a significant impact on the normative institutionalization of RtoP and its practical implementation.

\section{Normative Institutionalization to Operational Implementation}

The process through which new ideas, or repackaged ones, become standards of practice and behavior in international affairs has had more and more attention associated with it since the 1990s. Finnemore and Sikkink's (1998) flagship work on processes through which ideas become embedded norms-norm life-cyclesbegan to map out the process through which norms are created or dismissed through discourse and practice. Contemporary scholarship has largely focused on either norm acceptance and institutionalization (Finnemore \& Sikkink, 1998; Risse, Ropp, \& Sikkink, 1999) or norm contestation and rejection (Wiener, 2008). A third branch of burgeoning literature sets aside the acceptance/rejection dichotomy on normative change and focuses upon "norm localization", where globally accepted norms take on a hybrid character combining the key characteristics of the global norm with local modifications that make them more contextually salient (Acharya, 2009). What is then key is the framing of the norm by either external or internal promoters to demonstrate the ways in which it fits into already existing local normative structures (Payne, 2001). This re- 
framing appears to be taking place in South East Asia (Caballero-Anthony, 2012; Honna, 2012; Teitt, 2011) but has been less successful in other regions where RtoP has been more vociferously contested, including the introduction of the Brazilian concept on "responsibility while protecting" (United Nations, 2011a). Here it is not the internalization of the norm that is occurring but rather a reframing of the norm by external activists in an attempt to make it more palatable to regional and state actors. What also needs to be further examined is the extent to which regional organizations themselves are politicizing the norm rather than localizing the international understanding.

International norms, such as RtoP, are intended to provide a framework of standards by which a state or group of states' behavior will be judged. The implication is that these norms provide a belief system that transcends a specific political or cultural context (Sikkink, 1998) and that they provide standards of appropriateness and clear legitimation discourses to guide the decision making of actors (Dingwerth, 2008). These standards of appropriateness, such as the protection of civilians for example, then become the primary measures of success for the organization.

As Sunstein (1997) argues, these social norms are then enforced through social sanctions. Resistance to these norms and the "moral cosmopolitanism" is then framed as illegitimate (Acharya, 2004). This was the argument made in relation to Kosovo, that the intervention was legitimate because of its humanitarian basis and that to question this was to question the moral authority of, not only the interveners, but the wider concept of humanitarian action.

The question of whether RtoP has evolved from an idea or principle to a norm in international affairs has garnered much attention in recent scholarship (Bellamy, 2009; Welsh, 2013). Contemporary research, however, seems to demonstrate a relative consensus that RtoP is a burgeoning norm, whose status could be solidified if it becomes a standard of behavior for states and interstate organizations on civilian protection. As such, scholarship has increasingly shifted the focus from questions surrounding the institutionalization of RtoP, to inquiries focused more heavily on its operationalization.

Since the adoption by the UNGA member states of WSOD in 2005, which included three paragraphs on RtoP, and UNSC resolution 1973 on Libya sanctioning the use of force to protect civilians, greater consensus on RtoP as a standard of state behavior on civilian protection has been reached, even while new areas of contestation and redefinition emerge. Recent scholarship has demonstrated that regional normative operationalization of RtoP is following a process of "norm localization" where RtoP is becoming regionalized, adopting localized adaptations through its operationalization in specific contexts (De Franco \& Peen Rodt,
2015; Dembinski \& Schott, 2014; Seaman, 2015). As De Franco and Peen Rodt (2015) argue, the institutional implementation that occurs once an organization has formally accepted a norm "can become a field of contestation and explain why norms are sometimes understood differently across or indeed within international organizations" (p. 46). The process of developing formal policy and legal mechanisms, or "implementing" the norm, creates standards of behavior that facilitate assessments of compliance (see Betts \& Orchard, 2014; De Franco \& Peen Rodt, 2015). Moving beyond tracing the political discourse or policy development of RtoP, recent scholarship has attempted to begin addressing its "operational implementation" or reactive practices defined by De Franco and Peen Rodt as "the norm's mainstreaming into existing policies and resource allocation" (2015, p. 46). This can begin to shed light on the ongoing contestation and rewriting of the norm, as well as they ways in which this contestation develops into responsive mandates and resources for specific crises, including towards Libya and Syria.

\section{European Union}

The European Union has long been argued to be a progressive institution with significant normative influence around the world. It has developed advanced capacity in the area of conflict prevention and conflict management, peacekeeping, and post-conflict reconstruction where it has sought to position itself as a leader on normative and humanitarian issues (Dembinski \& Schott, 2014; Manners, 2006). As such, its influence has local and global implications.

The EU's evolving foreign policy orientation has become increasingly human security-focused (Liotta \& Owen, 2006a). Building on the 2003 European Security Strategy (ESS), the 2004 Barcelona report, A Human Security Doctrine for Europe, argued that the EU should place human security at the core of its foreign policy. The Study Group that authored the report argued that, "Human security refers to freedom for individuals from basic insecurities caused by gross human rights violations placing the protection of individuals" (Kaldor et al., 2004, Executive Summary). The report claimed that the EU's human security doctrine ought to place priority upon "human rights, clear political authority, multilateralism, a bottom-up approach, regional focus, the use of legal instruments, and the appropriate use of force" (Kaldor et al., 2004, Executive Summary). The Study group also recommended that a "Human Security Response Force" composed of 15,000 men and women drawn from both civilian and military institutions be created, as well as "A new legal framework to govern both the decision to intervene and operations on the ground" (Kaldor et al., 2004, Executive Summary). The Barcelona Report greatly influenced the ways in which human security ideas were more com- 
prehensively incorporated into the 2008 European Security Strategy (ESS) and within the European Commission, including on such issues human rights protection, responses to human trafficking, and nuclear nonproliferation (See De Franco \& Peen Rodt, 2015; Martin \& Owen, 2010).

While taking a decidedly robust position on the need for the EU to lead the way on the provision of security for people inside and outside its geographical purview, the Barcelona Report's articulation of human security relates narrowly to situations where individuals are under threat of, or actively being targeted by, violent repression (Liotta \& Owen, 2006a). Additionally, the connection between these broad-based humanfocused security activities and RtoP is decidedly absent from the EU's foreign and security policy mandates, including those that have adapted to a core human security doctrine. The EU has articulated its support for the UN's 2005 WSOD RtoP articulation, reifying the central role of the state to protect its citizens, however, it has remained extremely reluctant to operationalize the norm itself, largely owing to internal political divergences on how or whether to proceed on the implementation of RtoP (De Franco \& Peen Rodt, 2015). Dembinski and Schott (2014) argue that while the EU has accepted the UN's approach on RtoP, it has shied away from the military intervention aspects outlined in pillar III, choosing instead to focus on its reputation as a humanitarian organization working towards preventive and rebuilding capacities. Despite the more interventionist positions of Britain and France in their roles as UNSC permanent-5 members, the EU's smaller member-states, such as Finland and Sweden, have held decidedly more neutral and non-interventionist postures on RtoP. Dembinski and Schott (2014) argue that the EU has "pruned international norms" to fit its existing niche activities:

"we find that the EU acknowledged the R2P after this concept has been approved by the World Summit and interpreted it in a way that corresponded with the existing European security culture and its focus on peace-building and preventive measures." (p. 370)

\subsection{The EU on Libya}

Since the onset of the peaceful political protests in Benghazi in February 2011 to oust authoritarian leader Muammar Gadaffi in Libya, and the ensuing repression of protesters by government forces, the international community was thrust into a complex RtoP crisis that tested its resolve to meet the commitments it made at the UNGA in 2005. There has been much debate about the EU's role in Libya, with some scholars arguing that there was divergence between rhetoric and action (Gottwald, 2012), while others asserting that the EU adapted RtoP to its existing human security mandates focused largely on development and crisis management (De Franco \& Peen Rodt, 2015; Dembinski \& Schott, 2014). The process of operationalization of RtoP in the Libyan case seems to highlight some dominant trends worthy of discussion.

Firstly, the EU has widely supported actions of the UNSC on Libya, including UNSC resolution 1973, while preferring to take a more active role in the preventive and humanitarian realms it currently operates within. Specifically, UN resolution 1973 :

"Authorises member states that have notified the secretary-general, acting nationally or through regional organizations or arrangements, and acting in co-operation with the secretary-general, to take all necessary measures, notwithstanding paragraph 9 of resolution 1970 (2011), to protect civilians." (United Nations, 2011d)

The European Council released statements supporting the UNSC resolution 1973, even though it voted not to pursue military intervention. Cleavages amongst its member states, notably Britain and France on the intervention side; and Germany and Sweden, as well as other smaller countries on the "soft power" noninterventionist side, revealed divergent perspectives on how best to handle the crisis. The EU initially sought preventive measures to compel Gadaffi's regime to relinquish its repressive campaign against the Libyan people. It pursued diplomatic channels, and released statements condemning the repression of peaceful demonstrations, and acknowledged its responsibility to protect the Libyan people. European Council President, Herman Van Rompuy stated "From the beginning of the crisis, the European Union was at the forefront: the first to impose tough sanctions; the first to impose a travel ban on leading figures in the regime; the first to freeze Libyan assets; the first to recognise the Interim Transitional National Council as a valid interlocutor" (See Van Rompuy, in Rettman, 2011). Van Rompuy even went so far as to argue that the EU facilitated the military airstrikes undertaken by the UK, France, and Belgium under NATO and UN auspices (Rettman, 2011).

Secondly, as critics argue, the EU did not adequately apply the Common Security and Defense Policy (CSDP) included in the Lisbon Treaty to the Libyan conflict, and instead, played a diluted role (Faleg, 2013). Due to a lack of consensus among EU member states on its role in "hard power" military interventions for RtoP cases, there remains significant debate about whether the reputation of the EU as a humanitarian, soft-power, and development-oriented institution meshes with its potential role as a military interventionist regional organization. Indeed, the history of European colonization and conflict has highlighted the reluctance of some EU members to contravene the 
non-interference principle until preventive and diplomatic means have been more thoroughly exhausted. The dilemma, however, remains salient when faced with populations enduring serious human rights violations where, as in the case of Libya, the perpetrators are the government leaders themselves. The EU will have to find a thoughtful way to adapt its preventive and crisis management lean, with its commitment to upholding and protecting human rights in RtoP cases. Otherwise, its state-centric orientation to RtoP will be analytically incoherent with its human securityoriented policy approach.

\subsection{The EU on Syria}

What began as peaceful protests in March 2011 in Syria on the tail-end of the Arab Spring movement for democratic revolution across the Middle East and North Africa (MENA), quickly turned into one of the most significant humanitarian crises since WWII. With 470,000 dead, and over 12 million people both internally displaced and fleeing across borders, the Syrian civil war between the Assad government and opposition forces, and Daesh (Islamic State in Iraq and Syria or ISIS) terrorism and territorial expansion has provided a recipe for disaster. The international community has largely been ineffective in its attempts to respond to the crisis, or mitigate the violence against civilians. Moreover, the international community, and the EU in particular, have demonstrated an incoherent posture regarding the influx of refugees fleeing the country and seeking asylum in Europe.

It is widely known that UNSC deadlock between the US, UK, and France on one side, and China and Russia on the other has forestalled any major attempt at military action in Syria to end the conflict and address the humanitarian crises. The reluctance on the part of China and Russia to support any proposed military measures in Syria is a reflection of their concerns with the "mission creep" that occurred in Libya after the NATO led airstrikes sanctioned by UNSC resolution 1973. While the UNSC resolution affirmed the use of force to protect civilians, it did not afford the authority to the UNSC to pursue regime change. The toppling of the Gadaffi regime was argued to have surpassed the mandate of resolution 1973. China and Russia tacit acceptance of the civilian protection mandate in Libya was soured, and has led to a concerted effort to block any UNSC resolutions on Syria that make reference to the use of force, or the removal of Assad from power.

The EU's response to the conflict in Syria included $\$ 3.5$ million in humanitarian assistance funding, and the imposition of economic sanctions (Pierini, 2014). These efforts had little effect on stemming the violence, or compelling any shift in approach by the Assad regime. Germany, the UK, and France remained active members of the "Friends of Syria" group within the UN, however, Germany was staunchly opposed to military action, and the UK limited its support for robust military action to supporting US-led operations. With the only operational support for US operations coming from France, the Syrian conflict was perceived as a proxy war between the US and Russia (Pierini, 2014).

The Daesh (Islamic State in Iraq and Syria or ISIS) expansion into Syria, and their onslaught against civilians has increased the human rights violations in Syria, and intensified the humanitarian crisis. The flow of internally displaced people (IDPs), and refugees moving through Turkey and seeking asylum in Europe is argued to constitute the greatest humanitarian crisis since WWII. The EU's failure to develop unified policy to address refugee flows has prompted Amelia Hadfield and Andrej Zwitter (2015, p. 129) to argue that, "Political responses to the crises within the Union have accordingly been largely crafted on national, rather than Union perspectives." The UK has framed the issue as a potential burden on its welfare system, while France and Germany have asserted that refugees contribute greatly to the welfare and economic systems that they enter into (Hadfield \& Zwitter, 2015). Hungary, notably one of the staunchest opposers of accepting refugees from Syria, has framed Syrian refugees as aggressors, bringing threats of Muslim terror into Europe (Hadfield \& Zwitter, 2015).

Despite the European Commission President, Claude Juncker's, attempt to reframe the EU's position in light of its own historical legacy-many Europeans descend themselves from refugees-in accordance with the 1911 Refugee Convention which grants the right of those fleeing persecution to seek asylum elsewhere, there has been little unification across EU member states on addressing the refugee crisis. The result has been a contrary practice to the international human rights and humanitarian norms that the EU espouses. Indeed, while the EU's division on RtoPparticularly the military enforcement measures-is unsurprising, its inability to unify around broad-based human security norms, such as protecting and ensuring safe passage for refugees fleeing conflict is testament to its inability to collectively operationalize "soft" norms. As Hadfield and Zwitter (2015, p. 131) assert that despite efforts to create a European Neighborhood Policy (ENP), which would unify the region and its foreign responsibilities, and broaden adoption of international legal norms, "a combination of cultural specificity preventing a common interpretation of those norms, and national and fundamental upsurges inhibiting their implementation has marked the region." Divergences within the EU on operationalizing RtoP and softer norms related to human security, such as facilitating refugee flows, demonstrate the disconnect between rhetoric and action and serve as a roadblock to effective humanitarian intervention.

In both cases, the EU has modified the norm of 
RtoP to fit with its existing prevention-focused humanitarian mandate. While the process of norm localization requires the inclusion of the new norm within existing mandates, there is a lingering question surrounding the extent to which the RtoP norm has sparked any marked change in the operations of the EU when faced with human rights abuses against civilians. What's new about the EU's practice in RtoP cases? In Libya, the EU sought not to apply its CSDP to assist the US-led NATO military operation to protect civilians, opting instead to focus on its crisis management and development capabilities. In Syria, the EU remained divided in whether to push for more robust action, particularly amongst those members who also hold positions in the UNSC. Even more striking, the EU has not adequately addressed a "soft" crisis resulting largely from conflicts in Syria, Afghanistan and Iraq which lies within human security mandates that are well-established, even if they are outside the RtoP normative frame. EU member states have evoked highly politicized arguments to constrain the EU on issues of military action, limiting the organization's ability to pursue more comprehensive and robust regional responses.

\section{The League of Arab States (LAS)}

The League of Arab States (LAS), more commonly referred to as the Arab League, is not a regional organization noted for interventionism. Founded in 1945 the LAS is based on a loosely binding pact designed to improve coordination on matters of common interest. The founding members also rejected violence as a means of resolving disputes, and in 1950 signed the Treaty of Joint Defence, determining an act of aggression against one member state as an act of aggression against all.

In 2004, the Council of the LAS adopted the Arab Human Rights Charter, which came into effect in 2008, and was part of a larger series of reforms of the LAS including the introduction of a peace and security council and the establishment of an interim Arab parliament. These reforms, whilst important, have not resolved underlying issues with the structure of the LAS, particularly in relation to the non- binding nature of many of the votes. Under the LAS charter only a unanimous vote binds all member states, a majority vote only binds those states that voted in favor of the resolution (Aljaghoub, Aljazy, \& Bydoon, 2013, p. 292). This voting structure has limited the ability of the LAS to respond to challenges where the preferences of member states are not aligned.

Following the 'Arab Spring' however crises in the region have spurred the LAS into more direct action leading to what some commenters are calling a paradigm shift within the region (Nuruzzaman, 2015). This shift was most clearly demonstrated by the Arab League's support for the UN Security Council Resolution 1973 on intervention in Libya. The support for this reso- lution, which was the first time the Security Council has authorized the use of force for humanitarian protection against the wishes of a functioning state, could be seen as an indication of the growing acceptance of the norm of RtoP in the region, particularly when coupled with the fact that every member of the LAS voted in favor of the WSOD in 2005 and actively participated in the discussions surrounding the meaning, definition and scope of the normative description outlined in paragraphs 138 and 139 . Questions as to the extent of this acceptance are however raised with the selectivity in the application of the norm in relation to regional crises, most notably the response to Syria where reference to RtoP by the LAS was conspicuously absent.

The question then becomes whether support for an intervention based on explicit reference to RtoP demonstrates a wholesale acceptance of the norm itself (Bin Talal \& Schwarz, 2013). Perhaps we are instead seeing a form of norm localization within the LAS where in response to the situations in both Libya and Syria the LAS is adding new insights to the debate around the global development of RtoP. For example, the Saudi Foreign Minister has suggested that responsibility involves arming the Syrian opposition (Khaleej Times Online, 2012) whilst other Arab states have interpreted the concept of RtoP as their responsibility to provide humanitarian aid and shelter to Syrian refugees (Bin Talal \& Schwarz, 2013), these suggestions fall outside of the WSOD description and open up more questions about the role of regional actors in adapting and localizing international norms and the acceptance of RtoP as outlined in the WSOD paragraphs.

\subsection{The LAS on Libya}

The LAS was quick to respond to the repressive actions of the Libyan state, following the peaceful protests prompted in part by the self-immolation of Mohammed Bouazizi in Tunisia on 17 December 2010, the trigger event for much of the "Arab Spring". The membership of Libya was suspended on the $22^{\text {nd }}$ of February 2011 and on the $12^{\text {th }}$ of March the LAS called for the implementation of a no-fly zone over Libya, in direct response to the threats issued by Gaddafi against the city of Benghazi (Leiby \& Mansour, 2011). The support of the LAS for a no fly zone was seen by many as a requirement for the adoption of resolution 1973 and as Dembinski and Reinhold (2011, p. 7) argue "tipped the balance in favor of those who had argued for the imposition of coercive measures."

The request of the LAS coupled with the participation of two of its member states in the coalition involved in the no fly zone, Qatar and the United Arab Emirates, prompted by what Bellamy refers to as the "al-jazeera effect" (Bellamy, 2011), provided the legitimacy and support which was necessary to avoid a veto by either Russia or China in the Security Council. In fact 
"The role of the Arab League in both calling for and supporting the intervention provided a veneer of regional legitimacy to a situation that was hotly contested by other regional actors, including the AU" (Seaman, 2015, p. 68). What is less clear are the reasons why the LAS utilized the frame of RtoP in reference to the Libyan situation which directly encouraged international intervention, rather than framing it as an emerging civil war which would have tempered the international response.

Throughout the crisis the LAS made direct reference to the RtoP obligations of the Security Council including in its statement on March $12^{\text {th }} 2011$ as well as focusing directly on the need to protect the civilian populations within Libya (League of Arab States, 2011). It is also interesting to note that in the text of resolution 1973 the UN Security Council made explicit reference to the need for any state taking action to consult with not only the UN Security Council but also the Secretary General of the Arab League (United Nations, 2011d). The resolution also made direct reference to the condemnation of Libya by the LAS and the call for a no fly zone, bolstering the legitimacy of the actions being authorized at an international level with regional support.

For some the intervention in Libya represents an ideal test case for the use of RtoP, with resolution 1973 affirming all three pillars of the norm, the importance of a state's responsibility to protect its populations highlighted by the failure of the Libyan state to protect its own citizens pillar one, the attempts by the international community to encourage the Libyan state to fulfill its obligations pillar two, and the action taken by the international community when the Libyan state failed to do so, pillar three (William \& Bellamy, 2012). The success of RtoP was however soon questioned with the limited international response to the developing crisis in Syria.

\subsection{The LAS on Syria}

In response to the actions of the Syrian government against its population, the LAS took a much more cautious approach. This reticence in calling for action or intervention can in part be attributed to the outcomes of the NATO intervention in Libya and the perception that the operation overstepped its boundaries. The limited response can also be attributed to the limitations of the voting patterns explored earlier, and is a clear demonstration that when there are internal divisions within the LAS or when the preferences of all member states do not converge around a single issue, then actions are limited. In its initial response, the LAS made no explicit reference to the RtoP, in direct contradiction to its earlier response to the crisis in Libya.

As the crisis developed, the LAS suspended Syria's membership in November 2011 and then moved to sponsor a peace plan in December of the same year.
This plan included establishing a monitoring mission within Syria, in order to observe the compliance of the Syrian government. However, as the violence continued to escalate the mission was withdrawn in January 2012 and in February the LAS stopped cooperating with the Syrian government after Assad rejected the proposed joint Arab League United Nations peacekeeping operation. Once this plan was rejected, the LAS and UN appointed Kofi Annan as their joint special envoy. He introduced a six-point peace plan, which rested on the implementation of a ceasefire beginning in April 2012. When this failed to materialize and after a further five months of limited progress, Annan announced his resignation as envoy, citing the 'destructive competition' between Russia and the other permanent members of the Security Council (The Guardian, 2012). The failure of the Annan peace plan highlights not only the importance of unity of purpose at the regional level but also at the international level if success is to be achieved.

The divisions within the LAS have worsened over time with Saudi Arabia, Qatar and other Gulf states openly backing the rebels, while others such as Algeria and Iraq maintain support for Assad. In the case of Syria, "The Arab League's role has become a drag because of the divisions," said one well-placed source. "It's not an asset but a hindrance" (The Guardian, 2014). The continued tensions within the organization, and the UN Security Council also led to the resignation of another joint Special Envoy, Lakdhar Brahimi in 2014, who had threatened to resign almost from the beginning of his mission in 2012. Despite the recognition by some members of the LAS, such as Saudi Arabia, that they have a moral responsibility to intervene and to protect civilians, it is clear that the continued lack of unity between member states has been a stumbling block in forging a comprehensive solution to the Syrian Crisis (Gulf News, 2011). When coupled with the limited agreement at the international level and the perpetual vetoes by Russia and China in the Security Council the inconsistency and selectivity in the application and implementation of RtoP is made abundantly clear.

\section{The African Union (AU)}

As the continent that has hosted the most cases of humanitarian interventionism, Africa has a complex and unique relationship with interventionism, which is evident in the history of the African Union (AU). In 2002, the Organisation of African Unity (OAU) disbanded and the AU was established, largely out of a necessity to better respond to the human rights violations occurring throughout the continent (Sarkin, 2010). UN Secretary General Kofi Annan recognised this need for reform in his Millennium Report to the UN General Assembly, in which he cited the 1994 Rwandan Genocide as one of the key cases demonstrating a need for the international community to rethink its stance on hu- 
manitarian intervention (United Nations, 2000). Annan's speech eventually led to the formulation of RtoP at the 2005 UN World Summit (Sarkin \& Paterson, 2010), and as such, RtoP is viewed as having African roots (Luck, 2008; Seaman, 2015).

The AU has affirmed its rhetorical support for RtoP in the last decade and has adopted a more interventionist stance. Due to the AU's Constitutive Act and the establishment of the Peace and Security Council (PSC), which handles issues related to RtoP, Africa's peace and security architecture "is arguably the closest institutional embodiment of RtoP's three pillar structure" (Williams, 2009, p. 400). While the AU's Constitutive Act does not use the language of RtoP, its principles resemble those of RtoP, specifically Article 4(h), which grants $A U$ members the right to intervene under certain circumstances:

"(h) the right of the Union to intervene in a Member State pursuant to a decision of the Assembly in respect of grave circumstances, namely: war crimes, genocide and crimes against humanity." (African Union, 2001)

However, critics of the AU's commitment to RtoP argue that there is divergence between the AU's rhetoric and action around the doctrine. Murithi (2012), Sarkin (2010) and Williams (2009), argue that the AU has not resolutely accepted RtoP and the WSOD because member states are concerned with threats to national sovereignty. During the 2005 World Summit, Zimbabwe's President, Robert Mugabe, expressed concern that a few powerful states would dictate the agenda of RtoP (Williams, 2009). Similarly, Murithi (2012, p. 662) writes that a key debate in the AU's dialogue on RtoP is whether or not the AU should "become the primary agent of humanitarian intervention" in Africa or whether that role should continue to be filled by foreign actors.

Another divergence between acceptance of RtoP in theory versus practice stems from a lack of consensus among member states. Many AU members lack political will and do not agree on how and when RtoP should be implemented (Williams, 2009). This division was evident in the case of Libya when AU members spilt the vote on Resolution 1973 (United Nations, 2011b).

\subsection{The AU on Libya}

From the outset, the $\mathrm{AU}$ was reluctant to intervene in the protests in Benghazi against Libyan leader Muammar Gadaffi in 2011, and the AU's failure to develop a coherent, unified response to the crisis resulted in diminished regional and global legitimacy of the organisation. Lack of coherence was most evident in in the AU's response to UN Resolution 1973, granted approval of a no-fly zone when "three African non-permanent members of the UNSC (Gabon, Nigeria, and South Africa) voted in favour" of the Resolution (Seaman, 2015, p. 68). Regarding RtoP, three main positions were forged by AU member states: one group, led by Uganda, South Africa, and Kenya, accepted Resolution 1973, but claimed that NATO's actions exceeded the bounds of the resolution; another group, championed by Rwanda, fully supported military intervention; and the third group, headed by Zimbabwe and Algeria opposed intervention because they viewed it as a ploy by western countries to remove Gadaffi from power an institute regime change (Kasaija, 2013). In response to the $A U$ 's ambivalence, the UN made the unilateral decision that Libya was an Arab state, not an African one, and that the "AU had no authority over North Africa" (Kasaija, 2013, p. 127).

Rather than supporting military intervention on the grounds of the doctrine of RtoP and the AU's Constitutive Act, the $A U$ forged a diplomatic solution involving negotiations and settlements. On March 10, 2011 the AU's Peace and Security Council met and proposed the creation of an ad-hoc committee of Heads of State to negotiate with Gadaffi and the political leaders of the rebel group, known as the National Transitional Council (NTC), in hopes that a group of high level leaders would possess enough clout to rally the support of the international community (Dewaal, 2012). The AU's peace settlement called for a ceasefire, delivery of humanitarian aid, protection of foreign nationals, a dialogue between rebels and the government, and an end to NATO's airstrikes (BBC, 2011). The peace settlement was received in two markedly different ways: Gadaffi accepted the proposal, but the National Transitional Council (NTC) in Libya rejected it on the grounds that the deal had zero provision regarding the ousting of Gadaffi (Adams, 2012; BBC, 2011).

The case of Libya highlights an overarching criticism of the $\mathrm{AU}$ : that the $\mathrm{AU}$ does not act as a collective body, as indicated by the tendency of member countries to "adopt positions that best serve their interests" (Murithi, 2012, p. 667). The NTC criticized the AU for doing just that:

\footnotetext{
"The NTC saw the AU, whose secretariat received substantial funding from Libya, as protecting Qaddafi's interests. They were especially sceptical given that two members of the delegation, President Jacob Zuma of South Africa and President Yoweri Museveni of Uganda, had already publicly criticized the NATO-led intervention." (Adams, 2012, p. 9)
}

The AU's diplomatic approach alone does not warrant its de-legitimization, but the AU's failure to develop a cohesive plan does and, perhaps, if the AU would have been able to convince the LAS or NATO to respond peacefully rather than with force, escalation of the Libyan conflict could have been avoided. However, 
due, in part, to misunderstandings around RtoP, the case of Libya highlights regional divergence on RtoP. The EU, LAS, and the AU each responded differently to the Libyan crisis, as a result of divergence in the views of member states regarding the implementation of RtoP, and differing regional interests. In the case of Libya, such divergence resulted in unintended consequences, which should facilitate a re-thinking about how RtoP should be implemented and the role of regional organisations in that implementation.

\subsection{The AU on Syria}

As the uprisings of the Arab Spring began to plateau at the end of 2011, a new series of protests began in Syria, which quickly escalated into the one of the worst contemporary humanitarian crises. The AU's proposed response to the Syrian crises was markedly similar to its response in Syria: negotiated peaceful resolution. In conjunction with Russia and China, the AU, especially Uganda and Ethiopia, expressed concern that foreign intervention could exacerbate the conflict, as it did in Libya, and thus advocated for no foreign military intervention (Interfax, 2012). While the language of RtoP was not prominent in the AU's remarks on Syria, the African Forum's Statement on the situation in Syria (2013) did refer to RtoP in its call for the $A U$ to act peacefully and adhere to international law.

The AU's largely non-interventionist stance on Syria may stem from the fact that Africa has hosted more cases of humanitarian intervention than any other continent, and its leaders have experienced, first-hand, the counteractive effects that unilateral interventionism can have on people and countries who are already subject to severe suffering. Additionally, Tom Wheeler of the South African Institute of International Affairs said that the $A U$ had no compelling reason to get involved in the events of Syria, especially considering the more localized unrest that was occurring in Egypt in 2013 and, more recently, in Burundi (Powell, 2013).

The case of Syria also demonstrates the lack of credibility that the $\mathrm{AU}$ possesses in the global arena. In an address to the 70th Session of the UN General Assembly in September 2015, President Mugabe of Zimbabwe said that the situation in Syria could have been prevented if non-interference had occurred and if the UN acted as a multilateral institution by including and respecting regional organisations such as the $A U$ (NewsdzeZimbabwe, 2015).

Even though the $A U$ accepts the tenants of RtoP in theory, it has failed on multiple occasions to operationalize the doctrine, and this failure presents obstacles to efficient and appropriate intervention, especially in cases such as Syria, where the massive flows of refugees and IDPs throughout the region have resulted in the worst humanitarian crisis since WWII. Whether regional organisations, and their member countries, choose to frame the migration crisis as a threat to national security, or as a humanitarian crisis that calls for comprehensive and cohesive reaction, can have a profound impact on the region's stability.

António Guterres, United Nations Commissioner for Refugees, addressed the consequences that the dire situation in Syria has on neighbouring countries, especially Lebanon, Jordan, Turkey, Iraq and Egypt (2014). While African countries, other than Egypt, are not hosting Syrian refugees, the economic and security threats of the massive displacement still reverberate throughout the African continent. In his remarks, Guterres asserts that crises of this scale do not have a solely humanitarian solution, but rather, the solution must be of a political nature, forged by the world's political leaders.

\section{Conclusion}

Regional organizations do play important roles in global governance on RtoP. We have seen that they can provide support to various preventative and responsive measures when faced with severe humanitarian crises. They have largely supported the UNGA's articulation of RtoP, playing the role of "regional contractor" when engaged in active roles under UN auspices.

RtoP within the regional context has been articulated in a number of ways, and while we see greater reference to the protection of civilians in the rhetorical sense, we often see a reframing of the RtoP norm that dilutes and constrains processes of norm localization, and inhibits normative change. The operationalization of this burgeoning norm does not appear to convey any greater regional responsibility to protect civilians than well-established regional norms.

Even more striking, however, is the lack of consensus and capacity to adequately address human security threats more broadly, such as the refugee crisis, which do not require consideration of military force. This sheds light on the lack consensus on more firmly established norms and mandates that are in line with traditional regional mandates within and outside their geographic areas of interest.

Regional organizations will only be capable of taking up the operationalization and implementation side of RtoP, and human security more broadly, if they can garner greater consensus on their policies vis a vis humanitarian crises, and develop national policies that are aligned with regional rhetoric.

Additionally, norm localization processes must maintain the core tenants of RtoP, and lead to measurable normative change, where the protection of civilians is an actionable outcome by regional organizations. Politicization and reframing of the norm of RtoP away from its core human-centered focus on protection will largely inhibit progress on implementation, and erode the international community's potential to actually save lives in RtoP cases. 


\section{Conflict of Interests}

The authors declare no conflict of interests.

\section{References}

Acharya, A. (2004). How ideas spread: whose norms matter? Norm localization and institutional change in Asian regionalism. International Organization, 58(2), 239-275.

Acharya, A. (2009). Whose ideas matter? Agency and power in Asian regionalism. Ithaca, New York: Cornell University Press.

Adams, S. (2012). Libya and the responsibility to protect (occasional paper series No. 3). New York: Global Centre for the Responsibility to Protect.

African Forum. (2013, September 5). Statement of the Africa Forum on the situation in the Syrian Arab Republic. Retrieved from http://sites.tufts.edu/rein ventingpeace/files/2013/09/STATEMENT-OF-THEAFRICA-FORUM-ON-THE-SITUATION-IN-SYRIA.pdf

African Union. (2001) Constitutive act of the African Union. Retrieved from: http://www.au.int/en/sites/de fault/files/ConstitutiveAct_EN.pdf

Aljaghoub, M. M., Aljazy, I. M., \& Bydoon, M. S. (2013). The Arab League. In G. Zyberi (Ed.), An institutional approach to the Responsibility to Protect (pp. 289311). Cambridge: Cambridge University Press.

Bachman, J. (2015). R2P's "ulterior motive exemption" and the failure to protect in Libya. Politics and Governance, 3(4), 56-67.

BBC. (2011, April 11). Libya: Benghazi rebels reject African Union truce plan. Retrieved from http://www. bbc.com/news/world-africa-13035501

Bellamy, A. J. (2009). Responsibility to protect. Cambridge: Polity Press.

Bellamy, A. J. (2011). Libya and the responsibility to protect: The exception and the norm. Ethics \& International Affairs, 25(3), 263-269.

Bellamy, A. J. (2014, January 13). Libyan case a red herring in Syrian dilemma. IPI Global Observatory. Retrieved from https://theglobalobservatory.org/2014/ 01/libyan-case-a-red-herring-in-syria-dilemma

Betts, A., \& Orchard, P. (Eds.). (2014). Implementation and world politics: how international norms change practice. Oxford: Oxford University Press.

Bin Talal, E. H., \& Schwarz, R. (2013). The responsibility to protect and the Arab world: An emerging international norm? Contemporary Security Policy, 34(1), 1-15.

Bures, O. (2006). Regional peacekeeping operations: Complimenting or undermining the United Nations Security Council? Global Change, Peace \& Security, 18(2), 83-99.

Caballero-Anthony, M. (2012). The responsibility to protect in Southeast Asia: opening up spaces for advancing human security. The Pacific Review, 25(1), 113134.
Chandler, D. (2004). The responsibility to protect? Imposing the 'liberal peace'. International Peacekeeping, 11(1), 59-81. Retrieved from http://iilj.org/cou rses/documents/DavidChandlerTheResponsibilitytoP rotect.ImposingtheLiberalPeace.pdf

Chandler, D. (2010). R2P or not R2P: More statebuilding, less responsibility. Global Responsibility to Protect, 2, 161-166.

De Franco, C, \& Peen Rodt, A. P. (2015). Is European practice of mass atrocity prevention emerging? The European Union, responsibility to protect and the 2011 Libya crisis. Politics and Governance, 3(4), 4455.

Dembinski, M., \& Reinold, T. (2011). Libya and the future of the responsibility to protect: African and European perspectives (No. 107). Frankfurt: Peace Research Institute Frankfurt.

Dembinski, M., \& Schott, B. (2014). Regional security arrangements as a filter for norm diffusion: The African Union, the European Union and the responsibility to protect. Cambridge Review of International Affairs, 27(2), 362-380.

Dewaal, A. (2012). The African Union and the Libya conflict of 2011. World Peace Foundation. Retrieved from https://sites.tufts.edu/reinventingpeace/2012/ $12 / 19 /$ the-african-union-and-the-libya-conflict-of2011

Dingwerth, K. (2008). From international politics to global governance: The case of nature conservation (GARNET Working Paper 46(08)). Bremen, Germany: Institute for Intercultural and International Studies, Universität Bremen.

Evans, G. (2004). The responsibility to protect: Rethinking humanitarian intervention. Proceedings of the Annual Meeting (American Society of International Law), 98, 78-89.

Faleg, G. (2013, December 17). The governance gap in European security and defence (No. 310). Brussels: Center for European Policy Studies. Retrieved from https://www.ceps.eu/system/files/PB310\%20Faleg\% 20on\%20CDSP_0.pdf

Finnemore, M., \& Sikkink, K. (1998). International norm dynamics and political change. International Organization, 52(4), 887-917.

Gottwald, M. (2012). Humanizing security? The EU's responsibility to protect in the Libyan crisis (FIIA Working Paper). Helsinki: The Finnish Institute of International Affairs.

Hadfield, A., \& Zwitter, A. (2015). Analyzing the EU refugee crisis: Humanity, heritage and responsibility to protect. Politics and Governance, 3(2), 129-135.

Haugevik, K. M. (2009). Regionalising the responsibility to protect: Possibilities, capabilities and actualities. Global Responsibility to Protect, 1(2), 346-363.

Honna, J. (2012) Japan and the responsibility to protect: Coping with human security diplomacy. The Pacific Review, 25(1), 95-112. 
Interfax. (2012, October 5). Russian presidential envoy: African Union, Russia oppose military intervention in Syria.

International Commission on Intervention and State Sovereignty. (2001). The responsibility to protect. Ottawa: International Development Research Center.

Kaldor, M., Albrecht, U., Chinkin, C., Dervis, K., Dwan, R., Giddens, A., . . Serra, N. (2004). A human security doctrine for Europe. Retrieved from http://www.lse. ac.uk/internationalDevelopment/research/CSHS/hu manSecurity/barcelonaReport.pdf

Kasaija, P. A. (2013). The African Union, the Libya crisis and the notion of 'African solutions to African problems. Journal of Contemporary African Studies, 31(1), 117-138.

Khaleej Times Online. (2012, January 6). Qatar says Arab monitors in Syria made mistakes.

League of Arab States. (2011, March 12). League of Arab States statement on the implications of the current events in Libya and the Arab position. Retrieved from: http://responsibilitytoprotect.org/Arab\%20Lea gue\%20Ministerial\%20level\%20statement\%2012\%20 march\%202011\%20-\%20english(1).pdf

Leiby, R, \& Mansour, M. (2011, March 12). Arab League asks U.N. for no-fly zone over Libya. The Washington Post. Retrieved from https://www.washingtonpost. com/world/arab-league-asks-un-for-no-fly-zone-over -libya/2011/03/12/ABoie0R_story.html

Liotta, P. H., \& Owen, T. (2006a). Why human security? Whitehead Journal of Diplomacy and International Relations, 7(1), 37-55.

Liotta, P. H., \& Owen, T. (2006b). Symbolic security: The EU takes on human security. The Journal of the US Army War College, 36(3), 85-102.

Luck, E. (2008). Sovereignty, choice, and the responsibility to protect. Global Responsibility to Protect, 1, 1021.

Manners, I. (2006). European Union, 'normative power' and the security challenge. European Security, 15(4), 405-421.

Martin. M., \& Owen, T. (2010). The second generation of human security: Lessons from the UN and EU experiences? International Affairs, 86(1), 211-224.

Morris, J. (2013) Libya and Syria: R2P and the spectre of the swinging pendulum. International Affairs, 89(5), 1265-1283.

Murithi, T. (2012). The African Union at ten: An appraisal. African Affairs, 111(445), 662-669.

Newsdzezimbabwe. (2015, September 28). Mugabe: Syrian crisis could have been avoided. Retrieved from http://www.newsdzezimbabwe.co.uk/2015/09/mug abe-syrian-crisis-could-have-been.html

Nuruzzaman, M. (2015). Rethinking foreign military interventions to promote human rights: Evidence from Libya, Bahrain and Syria. Canadian Journal of Political Science, 48(3), 531-552.

Paris, R. (2014). The "responsibility to protect" and the structural problems of preventive humanitarian intervention. International Peacekeeping, 21(5), 569603.

Payne, R. A. (2001) Persuasion, frames, and norm construction. European Journal of International Relations, 7(1), 37-61.

Pierini, M. (2014, June 9). The European Union's concerns about Syria. Carnegie Europe. Retrieved from http://carnegieeurope.eu/publications/?fa $=55851$

Powell, A. (2013, August 29). South Africa opposes Syria strikes. Voice of America. Retrieved from http:// www.voanews.com/content/south-africa-jacob-zum a-opposed-to-us-international-military-strikes-on-syr ia/1739566.html

Rettman, A. (2011, April 5). Van Rompuy: EU should take credit for Libyan action. EU Observer. Retrieved from https://euobserver.com/foreign/32128

Risse, T., Ropp, S. C., \& Sikkink, K. (Eds.). (1999). The power of human rights: International norms and domestic change. Cambridge: Cambridge University Press.

Sarkin, J. (2010). The responsibility to protect and humanitarian intervention in Africa. Global Responsibility to Protect, 2(4), 371.

Sarkin, J., \& Paterson, M. (2010). Special Issue for GR2P: Africa's responsibility to protect. Global Responsibility to Protect, 2(4), 339-352.

Seaman, K. (2015). The regionalization of the responsibility to protect. In D. Fiott \& J. Koops (Eds.), The Responsibility to Protect and the third pillar (pp. 58-77). London: Palgrave Macmillan.

Sikkink, K. (1998). Transnational politics, international relations theory and human rights. Political Science and Politics, 31(3), 516-523.

Sunstein, C. R. (1997). Free markets and social justice. Oxford: Oxford University Press.

Taft, P., \& Ladnier, J. (2006). Realizing never again: Regional capacities to protect civilians in violent conflicts. Washington, DC: The Fund for Peace. Retrieved from http://reliefweb.int/sites/reliefweb.int/files/res ources/F67661CB88AF5808C12573A9004CB61Dfund_jan2006.pdf

The Guardian. (2012, July 6). Kofi Annan attacks Russia and West's 'destructive competition' over Syria. Retrieved from http://www.theguardian.com/world/ 2012/jul/06/kofi-annan-syria-destructive-competition ?INTCMP=SRCH

The Guardian. (2014, May 1). UN looking for Syria envoy as Brahimi prepares to quit after failed peace talks. Retrieved from http://www.theguardian.com/world/ 2014/may/01/un-search-syria-envoy-lakhdar-brahim i-quit

Teitt, S. (2011). The responsibility to protect and China's peacekeeping policy. International Peacekeeping, 18(3), 298-312.

United Nations. (1945, October 24). Charter of the United Nations. Retrieved from http://www.un.org/ 
en/sections/un-charter/chapter-viii/index.html

United Nations. (2000, March 27). Report of the Secretary General. New York, NY: UNGA. Retrieved from http://www.un.org/en/ga/search/view_doc.asp?sym bol=A/54/2000

United Nations. (2005, October 24). World Summit outcome document (A/res/60/1). New York: UNGA. Retrieved from http://www.ifrc.org/docs/idrl/I520EN. pdf

United Nations. (2011a, November 9). Letter dated 9 November 2011 from the Permanent Representative of Brazil to the United Nations addressed to the Secretary-General (A/66/551-S/2011/701). New York: UNGA.

United Nations. (2011b, March 17). Security Council approves 'no-fly zone' over Libya, authorizing 'all necessary measures' to protect civilians, by vote of 10 in favour with 5 abstentions. New York: UNSC. Retrieved from http://www.un.org/press/en/2011/ sc10200.doc.htm

United Nations. (2011c, February 26). Security Council resolution 1970. New York: UNSC. Retrieved from http://www.un.org/en/ga/search/view_doc.asp?sym bol=S/RES/1970(2011)

United Nations. (2011d, March 17). Security Council resolution 1973. New York: UNSC- Retrieved from http://www.un.org/en/ga/search/view_doc.asp?sym bol=S/RES/1973(2011)

Welsh, J. (2013). Norm contestation and the responsibility to protect. Global Responsibility to Protect, 5(4), 365-396.

Wiener, A. (2008). The invisible constitution of politics: Contested norms and international encounters. Cambridge: Cambridge University Press

Williams, P. (2009). The "responsibility to protect", norm localisation, and African international society. Global Responsibility to Protect, 1(3), 392-416.

Williams, P., \& Bellamy, A. J. (2012). Principles, politics and prudence:" Libya, the responsibility to protect, and the use of military force. Global Governance, 18(3), 273-297.

\section{About the Authors}

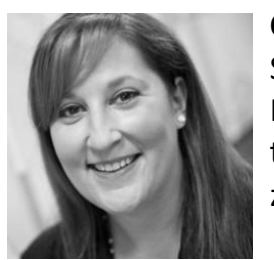

Carla Barqueiro is an assistant professor in the College of Public Affairs at the University of Baltimore. She teaches on the graduate program in Global Affairs and Human Security, and the undergraduate International Studies program. Her areas of research largely focus on human security issues, including the prevention of genocide and mass atrocities, the responsibility to protect, human rights, and citizen security.

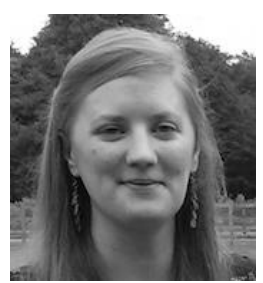

Kate Seaman is an adjunct professor at the School of Public and International Affairs at the University of Baltimore. Her research is focused on emerging norms of global governance and their impact on United Nations peacekeeping operations.

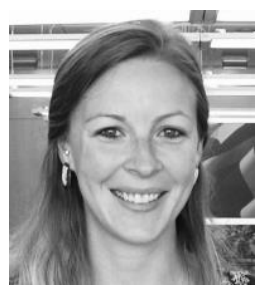

Katherine Teresa Towey is currently pursuing her M.A. in Global Affairs and Human Security at the University of Baltimore where she recently completed a yearlong research fellowship. Her research has focused on human security issues and immigration policy in the United States and abroad. Previously, she worked in the non-profit sector where she designed and implemented academic programming for middle and high school refugee, asylee, and immigrant youth in Baltimore City. 